Classification

Physics Abstracts

81.70.Yp

\title{
Estimate of Industrial Mineral Grade by Image Analysis and Geostatistics. Application to Glomel Andalusite Deposit (France)
}

\author{
Nadine Ricard and Dominique Lafon \\ École des Mines d'Alès, LP3MG, 6 avenue de Clavières, 30319 Alès cedex, France
}

\begin{abstract}
Résumé. - L'objectif de cet article est de proposer une nouvelle méthode d'estimation de teneur minérale qui associe deux techniques : l'analyse d'images et la géostatistique. Appliquée à la carrière d'andalousite de Glomel (France), cette méthode comprend deux étapes essentielles. Tout d'abord, une mise au point du mode d'échantillonnage et de mesure permet une évaluation de la densité surfacique en andalousite sur une image de front de taille, et ce avec une erreur faible. Ensuite, les techniques de la géostatistique permettent de passer d'une évaluation sur une image à une estimation sur un volume de tir de mine, et ce avec une erreur d'estimation qui sera à calculer.
\end{abstract}

\begin{abstract}
The purpose of this paper is to propose a new estimate method of mineral contents which associates two techniques: image analysis and geostatistics. Applied to the andalusite deposit of Glomel (France), this method is inclusive of two essential stages. First, an improvement of the measure and sampling mode allows an estimation of the surface area of andalusite on an image from a working face, with a small error. Then, geostatistical techniques allow an estimate on a blasted volume from the measurement of the surface area. Error of estimate is calculated.
\end{abstract}

\section{Introduction}

Andalusite is principal utilized in making refractory products. Damrec's surface mine at Glomel in France (Brittany) produces up to $0.6 \mathrm{~m}$. t. p.a. of crude andalusite (Fig. 1). Output is marketed to the refractories industry.

The Glomel andalusite open deposit consists in a dark andalusitic schist. Andalusite crystals are well developped. They can be observed as white rods with a section from 1 to $5 \mathrm{~mm}$ and length of several centimeters (Fig. 1). They contrast with the matrix. Mean andalusite content in the deposit is about $25 \%$. However local andalusite grade is highly variable along the deposit. Blasting control and ore treatment depend highly on estimate of andalusite grade spatial variability. At the present time, a prospection is performed which consists in:

- a sampling campaign (drillings, and cutting sampling),

- a physico-chemical analysis of samples and mapping of andalusite grades. 

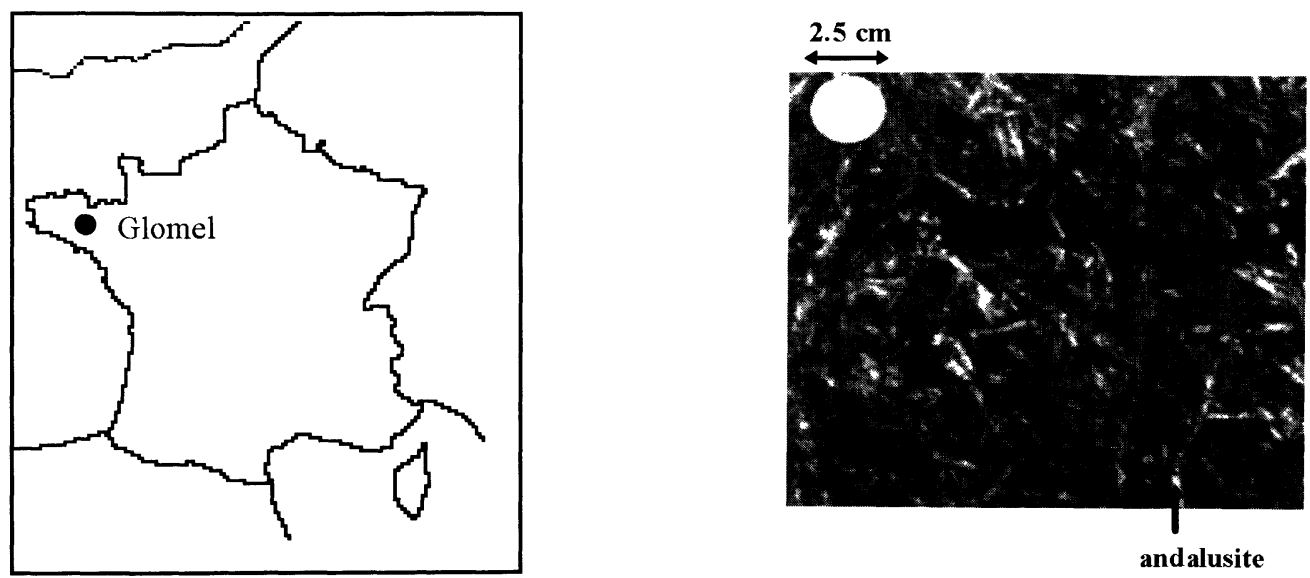

Fig. 1. - Glomel andalusite open pit: geographic situation and working face aspect.

These steps however are time consuming and expensive. A new method is proposed that associates image analysis and geostatistics to estimate andalusite grade. It consists in a three steps approach:

- sampling: photographs are taken on the working face. The established sampling plane takes into account the heterogeneous distribution of andalusite,

- measurement: an andalusite surface area is measured on each photograph by image analysis,

- estimate of andalusite grade in a $1800 \mathrm{~m}^{3}$ volume by geostatistics (broken ore obtained from one blasting).

\section{Estimate of Andalusite Volumic Density from a Sample}

A sample consists in a black and white photograph taken on the working face. Each image covers a $20 \times 20 \mathrm{~cm}$ area. Chosen scale allows a correct observation of andalusite crystals.

Each photograph is digitized and automatically processed in order to determine an andalusite surface area. Measurement of andalusite surface area on a binary image is based on point counting. In order to obtain an accurate estimation of andalusite surface area, the two major problems that face us are:

- technical problems that occur when taking of photographs is performed in the open quarry,

- sampling problem when photograph digitalization is performed.

2.1 Obtaining of an Accurate Digital Image. - Weibel [1] estimates the minimum number $N$ of points necessary to evaluate a surface area by point counting, in accordance with the volume fraction $V_{\mathrm{V}}$, by the next formula:

$$
N=\frac{t^{2}\left(1-V_{\mathrm{V}}\right)}{d^{2} V_{\mathrm{V}}}
$$

where $d=$ accuracy, $t=$ variable of a reduced centered law $=1.96$ with a probability error of $5 \%$. With an average andalusite volume fraction of $25 \%$ and accuracy of $2 \%$, digital images must contain at least 28800 pixels. 
Chosen digital image resolution is: 1 pixel $=1 \mathrm{~mm}^{2}$ (sampled area of $20 \times 20 \mathrm{~cm}$ ). Digital image contains $256 \times 256$ pixels and each pixel has a 8-bit gray scale value. Andalusite rod sections are sampled by at least 10 pixels. It guarantees an accurate estimation of the andalusite surface area in accordance with Weibel's preconisations.

2.2 Image Processing AND AnAlysis. - Initial noisy images (Fig. 2a) have to be processed before thresholding and quantitative analysis. The different defaults of initial images are those binded to working face irregularities, to exposure conditions (variable lighting, climatic conditions) and to acquisition system and image transfer. The image processing is carried out through 5 stages:

Stage 1: we are faced with a problem of variable lighting during the exposure. Resulting defaults must be corrected. An anamorphose is applied that enhances the dynamic range of the image (histogram stretched between 0 and 255) and equilibrates the histogram (improvement of the contrast between andalusites and background) (Fig. 2b).

Stage 2: image background (matrix) is homogenized by a morphological filter. An opening by a segment is performed in each main direction of the grid. This filter extracts andalusite rods from previous image and emphasizes the lighting variations. The filter image is then substracted from the previous one; the background of the resulting image is uniform and andalusite are more contrasted (Fig. 2c).

Stage 3: a median filter removes noise. In the output image andalusite boundaries are preserved; the light phase corresponds exactly to the andalusite rods and the dark phase corresponds to the schistose matrix (Fig. 2d).

Stage 4: the characteristics of the grey level histogram of this image allow an automatic segmentation of previous image using the histogram variance $[2,3]$. The level of the threshold is automatically computed by maximizing the within-class variance (Fig. 2e).

Stage 5: the andalusite surface area $A_{\mathrm{A}}$ is approximated by the number of white pixels on the binary image weighted by the total number of pixels (number of white pixels/total number of pixels of the image).

Estimate of measurement error has been accomplished using Gy's theoretical work [4]. The proposed method gives results with a global error ranging between -1 and $+3 \%$ (with a first kind error of 5\%) [5]. A larger amount of error can be achieved on very spoiled working face.

The andalusite density estimate is performed on a section. The basic equation for determining volume fraction $V_{\mathrm{V}}$ from surface area $A_{\mathrm{A}}$ may be expressed as follows [1]:

$$
V_{\mathrm{V}}=A_{\mathrm{A}} .
$$

The studied section must be a representative sample. Therefore preferential orientation of andalusite rods may give rise to anisotropy. A geostatistical study performed on one image has shown that andalusite rods orientations in the three-dimensional structure is isotropic in most parts of the deposit [5]. This finding agrees with the use of the above equation; the andalusite grade of a sample can be directly estimated (\% in volume).

\section{Design of an Accurate Sampling Program}

A correct sampling must be carried out in order to access the andalusite grade on a $1800 \mathrm{~m}^{3}$ ore block (broken ore obtained from one blasting) from previously described measurements. Knowledge of the andalusite spatial distribution in exploited orebody is necessary to optimize sampling pattern. Geostatistics deal with the spatial variability and can provide an unbiased and accurate estimate of the mean grade of a block $[6,7]$. The geostatistical andalusite grade estimation can 

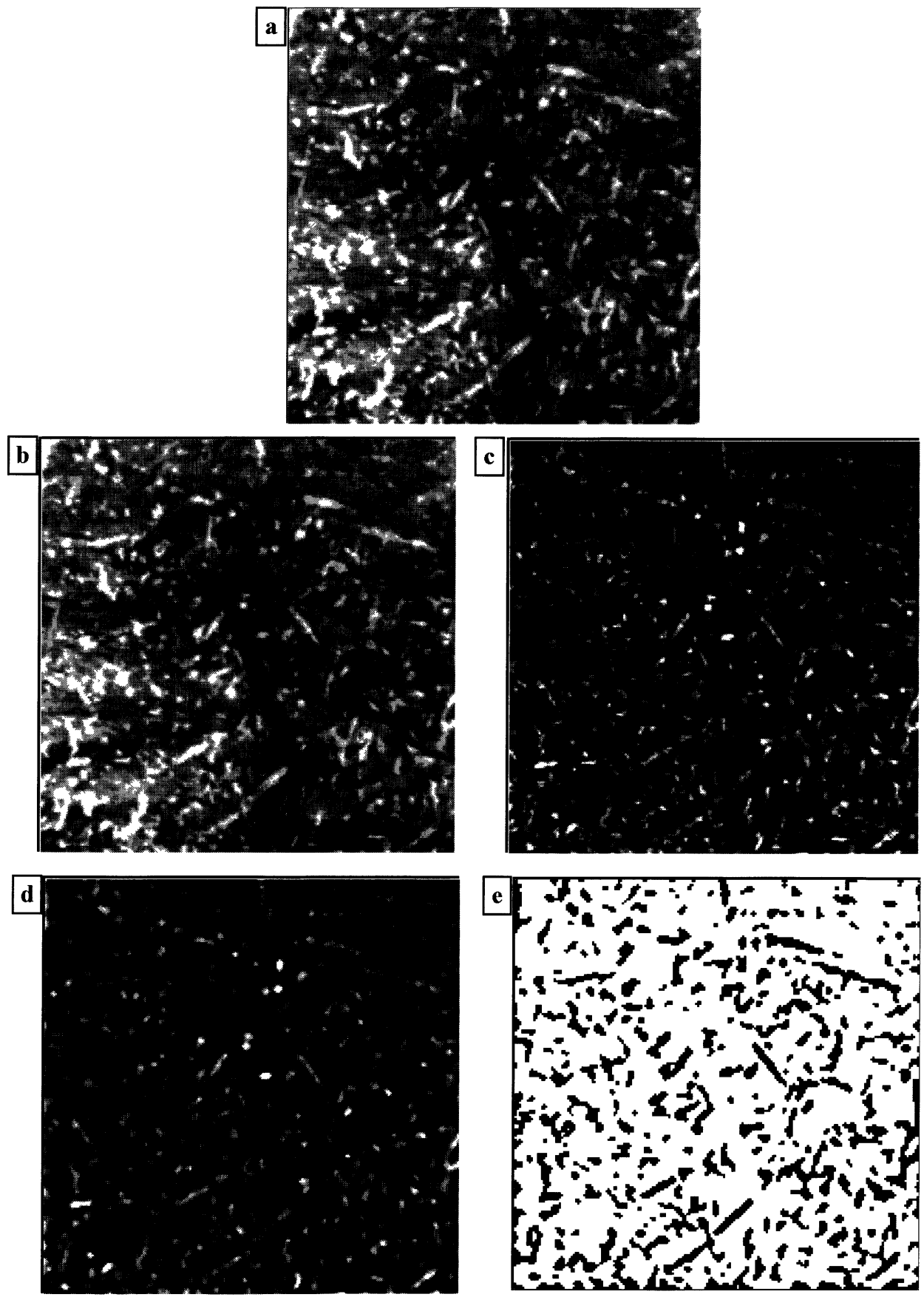

Fig. 2. - Image processing: a) initial image, b) anamorphosis, c) morphological filtering, d) median filtering, e) automatic threshold. 


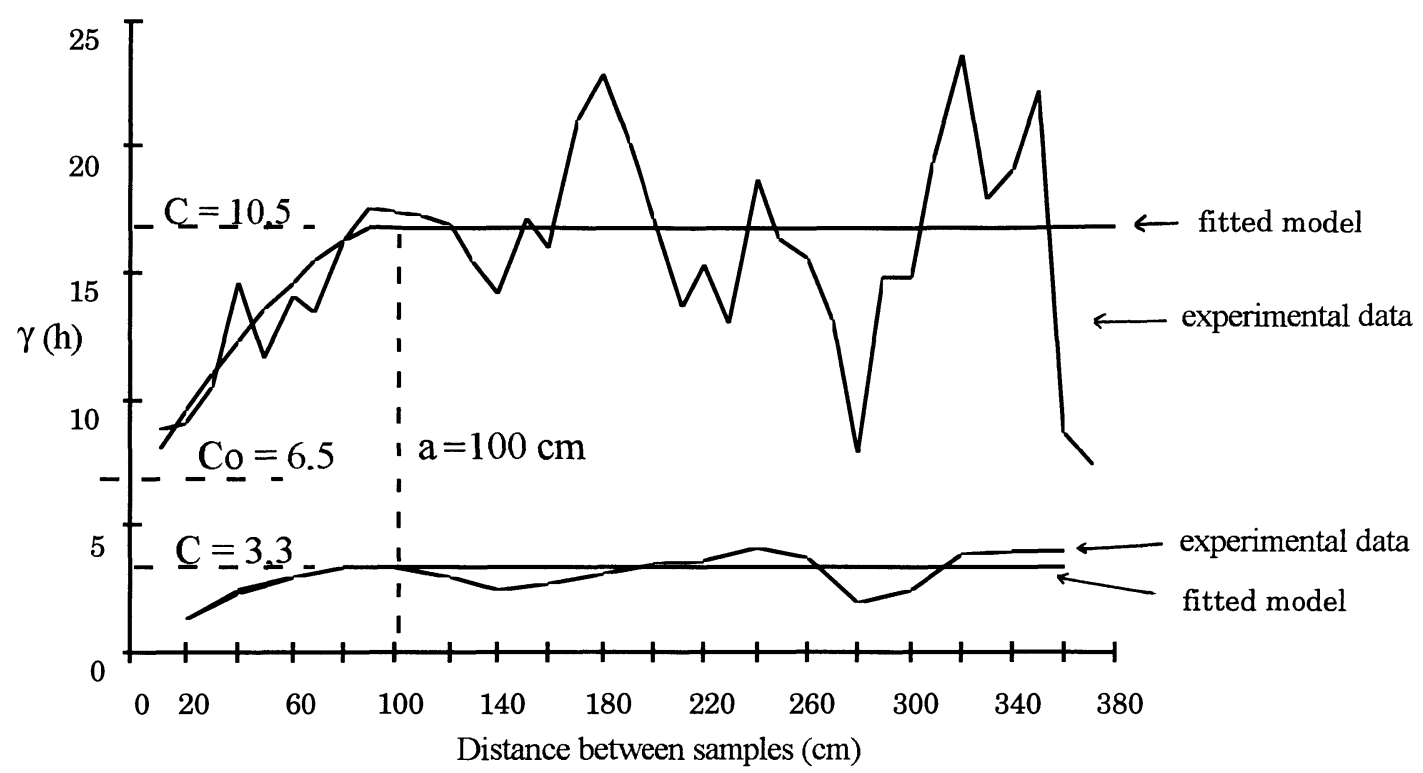

Fig. 3. - Small-scale horizontal variograms: experimental curves and fitted theoretical models.

be divided into two parts. At first the orebody structure must be investigated by means of a variogram study. The average square difference in andalusite grade between samples is calculated at increasing distances between sample points. Then it is represented on an experimental variogram. The second stage of the procedure is the estimation process which depends entirely on the variogram study.

3.1 Investigation and Modeling of the Orebody Structure. Variogram study. A multiscale geostatistical study is carried out in Glomel open pit:

- A small-scale study is performed along several lines on working faces (lines length $=3$ meters). Contiguous images are taken all along this lines and then analysed. The obtained variograms (Fig. 3) present a one meter horizontal range denoted by $a$ in Figure 3. It indicates the existence of a one meter scale spatial organization.

- This first result allows a new sampling on a longer horizontal line with a realistic number of non contiguous samples. This second study gives information about orebody structure at the scale of a blasted block (horizontal length $=30 \mathrm{~m}$ ). The achieved variogram is presented in Figure 4: it shows two ranges $\left(a_{1}=2 \mathrm{~m}-a_{2}=12 \mathrm{~m}\right)$. It indicates a vertical structural organization at the block scale.

A vertical variogram study was performed. The experimental variogram did not detect any horizontal structure.

3.2 Optimization of Sampling Program. Reliability of estimate. - The blasted block to be estimated is a parallelepiped $(30 \times 12 \times 5 \mathrm{~m})$. Variogram study is used to calculate the block estimate and associated estimation variance (error associated to the estimate) by kriging.

The estimation variance of andalusite grade was calculated from a line of $N$ regularly distributed photographs on a surface 30 meters long by 2 meters high and on a surface 30 meters long by 10 meters high. The achieved results are presented in Figure 5. 


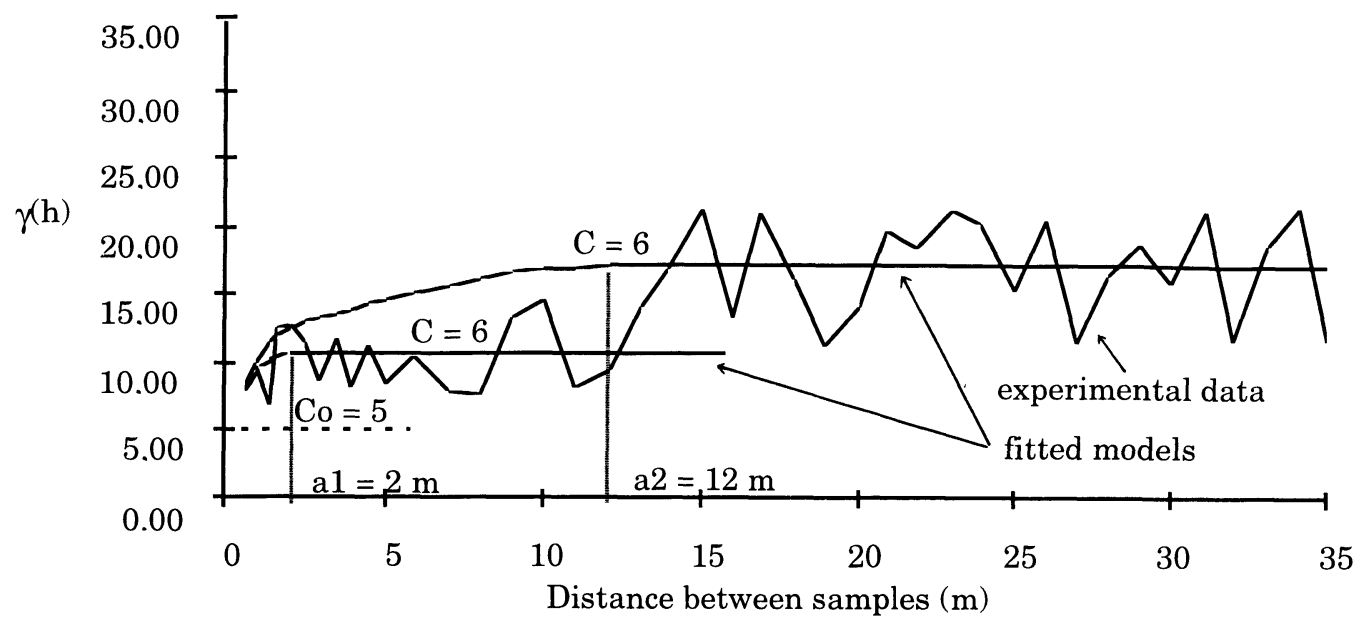

Fig. 4. - Large-scale horizontal variogram: experimental curves and fitted theoretical models.

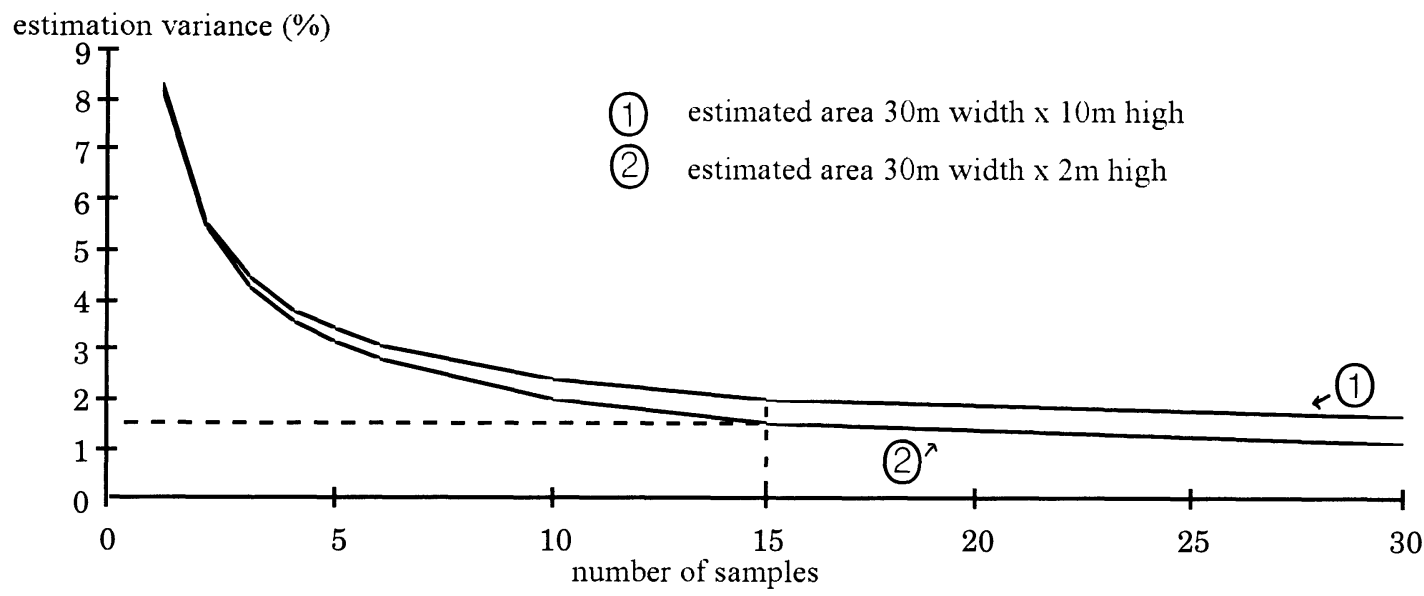

Fig. 5. - Evolution of the estimation variance according to the number of samples regularly distributed on a line.

The error associated to the andalusite grade estimate is equal to $2 \%$ with a sampling pattern consisting in 15 photographs regularly distributed on a 30 meters long horizontal line.

\section{Conclusion}

Image analyse associated with geostatistics allows the andalusite grade estimate on a large volume corresponding to one blasting. The proposed technique takes into account economic technic and geologic constraints.

Compared with drilling and physico-chemical analysis, image analysis is an easy-to-use and cheap technique. It is automatic and non destructive and it gives accurate results. Geostatistics 
is useful in the spatial characterization of ore deposit:

- Ore visual observations have been performed in the open pit; no geological structure has been clearly detected. By pointing out a "hidden" spatial organization, geostatistic analysis allows an unbiased and accurate andalusite grade estimate. This analysis is time-consuming but it is done once for all on the deposit.

- The photographs are representative of the local andalusite grade; geostatistical analysis does not detect a centimeter-scaled structure beside the structure related to andalusite crystals. 15 photographs $(20 \times 20 \mathrm{~cm})$ are enough to estimate properly mean andalusite grade for broken ore obtained from one blasting.

Improving the measurement and sampling mode, and the sampling pattern according to the material structure can be directly transposed to other fields.

\section{Acknowledgements}

Much gratitude is owed to Denain-Anzin Minéraux S:A. for their help to realize this research.

\section{References}

[1] Weibel E R., Stereological Methods: Practical Methods for Biological Morphometry (Academic Press, 1979) vol. 1, pp. 1-339.

[2] Zeboudj R., Filtrage, seuillage automatique, contraste et contours : du pré-traitement à l'analyse d'images, Thèse de 3 cycle l'Université de Saint Étienne (1988).

[3] Otsu N., A thresholding selection method from grey - level histograms, IEEE Trans. Systems, Man and Cybernet. 9 SMC (1979) pp. 62-66.

[4] Gy P., Homogénéité, hétérogénéité, échantillonnage (Masson Ed., 1988).

[5] Ricard N., Estimation de teneurs en minéraux industriels par analyse d'images in situ. - Application au gisement d'andalousites de Glomel (Côtes d'Armor), Thèse de Doctorat de l'Université de Montpellier II (1995) 95MON2035.

[6] Matheron G., La théorie des variables régionalisées, et ses applications. Cahiers du Centre de Morphologie Mathématique, École des Mines de Paris - Fontainebleau, Fascicule $n^{\circ} 5$ (1970).

[7] Hersant $T$ et Jeulin D., Léchantillonnage dans les analyses quantitatives d'images. Exemple d'application aux mesures de teneurs de phases dans les agglomérés et des inclusions dans les aciers, Mém. Sci. Rev. Met. 73 (1976) 503. 